\title{
Social Capital and Trust in Collaborative Marketing Groups: the case of Vegetable Clusters in the Southern Philippines
}

\author{
J.T. Axalan. S.B. Concepcion, M.O. Montiflor, R.J.G. Lamban and R.R. Real \\ School of Management \\ University of the Philippines Mindanao \\ The Philippines \\ P.J. Batt, R.B. Murray-Prior and M.F. Rola-Rubzen \\ Curtin University \\ Perth \\ Western Australia \\ F.T. Israel, D.I. Apara and R.H. Bacus \\ UP Strategic Research and Management Foundation Inc. \\ University of the Philippines Mindanao \\ The Philippines
}

Keywords: social capital, trust, vegetables, cluster marketing, Southern Philippines

\begin{abstract}
Over the past two decades, numerous studies have explored the role and the impact of social capital in organizations. Social capital helps overcome problems of institutional access to information, credit, the supply of farm inputs and the provision of government services. Despite the increasing number of studies, the role of social capital and trust in collaborative marketing arrangements for smallholder producers remains relatively unexplored. This study examines social capital among cluster marketing groups in three regions of the Southern Philippines. The results show that social capital in the form of affiliations and networks, social cohesiveness, open communication and trust had positive benefits for each of the cluster marketing groups.
\end{abstract}

\section{INTRODUCTION}

Social capital has been described as an intangible asset that has a significant influence on the daily lives of people. It includes the goodwill, fellowship, sympathy and social intercourse among individuals and families who make up a social unit (Productivity Commission, 2003). Ostrom (2000 p. 176) defines social capital as the shared knowledge, understandings, norms, rules and expectations about patterns of interactions that groups of individuals bring to a recurrent activity. While Bowes and Gintis (2002) suggest that social capital refers to trust, concerns for one associates and a willingness to live by the norms of one's community, Putnam (2000) sees social capital as including the social networks, norms of reciprocity and trust that enable members of a community to more effectively pursue shared objectives.

Within a society, social capital includes the institutions, the relationships, the attitudes and values that govern interactions among people and contribute to economic and social development (Productivity Commission, 2003). Social capital includes the shared values and rules for social conduct expressed in personal relationships, trust and a 
common sense of civic responsibility that makes society more than just a collection of individuals (World Bank, 1998).

Numerous studies have explored the role and the effect of social capital on organizations. Some of the findings show that local associations and networks have a positive impact on economic welfare and local development (Feldman and Assaf, 1999). Woolcock and Narayan (2000) identify social capital as having both vertical and horizontal associations between people, and relationships within and among other organizational entities such as community groups and firms. They distinguish between "bonding" and "bridging" social capital, where bonds refer to the intra-community ties that enable poor people to "get by", whereas bridging refers to the extra-community networks that enable individuals and groups to tap outside resources to "get ahead" (Gittel and Vidal, 1998). Social capital helps overcome problems of institutional access to information, credit, the supply of farm inputs and the provision of government services (Paryhasarathy and Chopde, 2000). In agriculture, where the active participation of cohesive farmer groups in development projects is often essential to achieve the project objectives, strong, well organized farmers' associations are better equipped to implement new technology, farming methods and crops.

However, without some foundation of trust, social capital cannot develop. Fukuyama (1995) defines trust as an expectation that arises within a community of regular, honest and cooperative behaviour, based on commonly shared norms. Social norms are related to trust through accepted rules, customs, norms and standards, which informally regulate transactions (Brenkert, 2000). Zucker (1986) reports how common values and norms based on kinship, familiarity, religion, ethnic status or family background provide solidarity between exchange partners. Granovetter (1985) considers trust to be based primarily in the social system, where individuals find themselves capable of trusting because of the social norms and networks within which they are embedded.

Despite the increasing number of studies into social capital, there is little empirical evidence of the benefits of social capital and trust in collaborative marketing arrangements for smallholder producers. This study examines social capital and trust among cluster marketing groups in three regions of the Southern Philippines for the purpose of encouraging greater dialogue between researchers, policymakers, government agencies, non-government agencies and smallholder farmers.

\section{METHODOLOGY}

\section{Site selection}

From 2008-2010, under a collaborative project supported by the Australian government, 29 vegetable clusters were formed in South Cotabato, Bukidnon and Davao, in Mindanao, the second largest island in the Philippines.

In South Cotabato, 135 smallholder farmers were organized into 12 clusters located in the municipalities of Lake Sebu, Tupi and Surallah. In Bukidnon, seven clusters with 67 members were located in Lantapan, Impasugong and Malaybalay City, while in Davao, ten clusters with 151 farmer members were organized in Calinan and Marilog districts. While some of the clusters cultivated just one variety of vegetable, others cultivated a range of mostly semi-temperate vegetables, depending on the needs of their identified buyer(s). 


\section{Data collection}

For this study, the majority of the information on social capital was sourced from key informant interviews, trip reports and focus group discussions with the farmers during agro-enterprise development activities in selected vegetable clusters in the Southern Philippines. The study focused on social capital indicators which include associations, affiliations, social cohesiveness and open communication.

In evaluating trust, farmers were asked to reflect on a number of trust measures developed by Batt et al. (2006). From 2010 to 2011, 81 vegetable farmers in Bukidnon, Davao and South Cotabato were asked to respond to a survey questionnaires that explored the level of trust within the clusters. In Davao, 33\% (50 out 151) of the population participated the survey, while South Cotabato and Bukidnon, the participation rate was $13 \%$ (17 out of 135) and 21\% (14 out of 67), respectively.

\section{RESULTS AND DISCUSSIONS}

\section{Social Capital}

Associations and networks. Before clustering was introduced in South Cotabato, some of the farmers in Lake Sebu were already members of the Ned Landcare Association Inc (NLCA), a farmers' organization facilitated by the Philippine-Australia Landcare (CRS) Project in 1999. In 2007, through Landcare, the NLCA were linked to the Catholic Relief Service and then, in 2008, to UP Mindanao. Under Landcare, the production and marketing systems adopted by the Ned farmers had been evolving. Relationships between the Landcare facilitators and local government units helped farmers in Ned link with other institutions. Not only did the farmers acquire good production skills, but they were willing to try new things. However, as the Landcare groups are well organised and high levels of social capital were already present the process of cluster formation proved to be much easier and proceeded much faster.

In the case of the Kablon clusters, the Tupi Municipal Agriculture Office (TMAO) partnered with the cluster groups. The partnership between the TMAO and the farmers made it easier for the cluster to access inputs and training from government agencies. In one instance, a rain shelter was provided to the cluster to demonstrate the importance of protected cropping in facilitating the production of high value vegetables all year round. The TMAO also provided the cluster with $8,000 \mathrm{G}_{1}$ seed potato tubers which were distributed to and multiplied by the cluster members.

Some of the cluster members in South Cotabato partnered with the Integrated Cooperative towards Unified Services (ICTUS), a cooperative that provided financial services. In order to get a loan, the cluster members had to first become a member of the bank and to attend a pre-membership seminar. A membership fee and initial savings had to be deposited, which amounted to $\mathrm{PhP} 1,700$ per farmer. In Ned, since few farmers could afford this initial cost, Landcare contributed funds to meet the short fall. A loan was released to the members of the cluster for $\mathrm{PhP} 10,000$ per farmer in the form of inputs.

In Bukidnon, external relationships also facilitated the formation of the clusters. Active participation and support from institutions like Kaanib, Landcare, the Bukidnon Cooperative Bank (BCB) and the Tinubdan sa Kalambuan Foundation Inc (TKFI) all contributed to the formation of the cluster groups. Like South Cotabato, Landcare provided technical and organizational development assistance to the Songco and Kaatuan clusters in Lantapan.

In Impasugong, Kaanib provided organizational and technology support to the clusters. The Department of Trade and Industry (DTI) conducted a training workshop on 
strategic enterprise development. The Department of Agrarian Reform (DAR) was also an active member of the Technical Working Group (TWG) who were involved in evaluating cluster development in the area. The Local Government Unit (LGU) supported and assisted in strengthening production. The office of Municipal Economic and Enterprise Development (MEEDO) provided marketing assistance, enabling the cluster to overcome several institutional constraints that prevented them from accessing high-value markets.

Cluster strengthening activities like planning, assessment and monitoring are usually untaken in close coordination with the partners. For Impasugong, it was CRS, Kaanib and MEEDO who guided cluster members in the implementation of the cluster enterprise plans. The current production cycle of sweet pepper in Lantapan was funded by the TKFI/BCB. Their technical officers ensured that the desired production protocols were observed throughout the production cycle.

However, in Lantapan, heavy unseasonal rain resulted in crop failure. As a result, the Municipal Agricultural Office (MAO) provided six rainshelters to the Paglambu cluster members as a means of providing a protected cropping system in the area. The Paglambu cluster was chosen because they were registered as a people's organization (PO), which enabled them to comply with the legal obligations to receive the grant. Aside from technical support, the partners were also able to assist in accessing credit. The Paglambu cluster was financially assisted by the BCB through the Tinubdan sa Kalamboan Foundation Inc (TKFI).

Like South Cotabato and Bukidnon, institutional support organizations have been crucial in the operation of the Davao clusters. Aside from market linkages, some clusters in Davao received material support and technical information from both government and non-government agencies. The Davao City Agriculturists Office (CAO) provided training in integrated pest management and a range of sustainable production technologies including vermiculture, composting, organic fertilizers and natural insect repellents, which the farmers applied on their farms. Aside from information dissemination, the cluster received plastic crates and seed trays through the High Value Commercial Crops program of the Department of Agriculture (DA-HVCC). Two cluster groups in Quirogpang and Saloy received seed support from the DA-HVCC, the City Agriculture Office (CAO) and UPSTREAM.

Social Cohesion. In South Cotabato, the Ned and Kablon clusters are a strong cohesive group. The cluster farmers have a history of working together, sharing knowledge and adapting farming practices to suit local conditions. Even without support, the farmers already help one another with farm activities and exchange information about how best to grow their crops. The Kablon and Ned clusters still practices dagyaw, where they help one another in planting and other activities without any monetary reward in the expectation that their efforts will be reciprocated when they need assistance. For the Ned cluster, farmers share a common goal to take good care of their land. It is a requirement for cluster membership that farmers must practice conservation farming.

In Davao, cluster group cohesion was facilitated by the social connections between members. This included belonging to the same family, being neighbours, belonging to the same church group and speaking the same language. For the Small Farmers Association of Quirogpang (SFAQ), for instance, 14 out of the 19 members belonged to just three families. Most of the members also speak Cebuano and belong to the same church group. 
Open communication. Cluster meetings provide an opportunity to assess performance against targets. With the opportunity for everyone to be involved and informed, trust is built. During these meetings, cluster members openly discussed problems encountered during the past delivery, suggested alternatives to these problems, presented the association's financial reports, assigned marketing officers for the forthcoming weeks, reported on the status of the production area, the expected date and volume of harvest, and reviewed/revised association policies. During the cluster meeting, part of the agenda is the sharing of technology among cluster members. This allows each cluster member to share their technical problems and good agricultural practices on farm.

For the Ned and Kablon clusters in South Cotabato, there is a schedule to visit other cluster member's farms to observe their performance. From these reciprocal farm visits, cluster members get information to improve their own farming techniques and the quality of produce, while at the same time, to strengthen group relationships. The sharing of technical information among cluster members also provides an environment for cluster members to build trust.

Trust. Utilising a number of trust dimensions developed by Batt et al. (2006), cluster farmers in South Cotabato indicated that the main reason for their having trust in the cluster was the confidence that they collectively shared. The main reason for the high level of confidence was the knowledge that through the cluster, they were able to access buyers for their products that acting individually they could not supply. They also indicated that they were actively involved in the implementation of plans and programs.

In Davao, the confidence that cluster members shared was derived from the good relationships that they had established with their fellow members and the unity among the members. Cluster members believed that their fellow farmers were sincere, honest and trustworthy. However, while some members trusted the cluster, they did not trust other cluster members. They perceived that some members were not honest and did not keep their promises. Like South Cotabato, farmers in Davao also attributed much of their trust in the cluster to the knowledge that they had buyers for their produce. Collectively, cluster members were confident that they could deliver the volumes required by their buyers and would achieve higher prices. Appropriate rules were in place to guide the cluster members.

For the Davao farmers, much of the trust in their cluster was derived from the information provided by the cluster. During cluster meetings, the members were informed about the prevailing market prices and where other cluster members had attended training sessions or technical workshops, that knowledge was shared with the cluster members. Through being a member of the cluster, farmers were able to access technical information that assisted them in improving production and/or to lower production costs. Every member of the cluster was informed about the clusters activities and progress towards its goals.

This was also true for the South Cotabato farmers. During monthly cluster meetings, farmers discussed the schedule of production, buyer's needs and market delivery, and the outcomes of any training programs cluster members had participated in.

In all the clusters in South Cotabato, Bukidnon and Davao, an element of honesty was observed. Honesty was instilled in the cluster members and facilitated through the transparent exchange of information and the receipt of appropriate payments from the sale of fresh produce through the cluster. A high degree of trustworthiness was evident between the farmers and the cluster. 
In South Cotabato, every member had an opportunity to say what they wanted to say and the group listened. Some farmers trusted the cluster because of the benefits they received like training and the implementation of plans and programs. Farmers mentioned that the group adhered to the policies they had established and there were sanctions for those who violated them. In Davao, a high level of trustworthiness was attributed to their cluster leader. The cluster leader was very active and trusted by the members.

The South Cotabato farmers believed that the cluster looked after the welfare of the members and their intentions were good. The cluster provided them with an additional source of income. Other benefits were derived from the technical knowledge and advice they acquired and shared with other cluster members. Collectively, the cluster scheduled plantings and frequently reviewed progress to ensure that customer's needs were fulfilled. In Davao, the farmers highlighted the support provided by the cluster such as seedlings and the high prices they received from the consolidation of their vegetables.

Trust is very much dependent upon the keeping of promises (Batt et al. 2006). While farmers in South Cotabato demonstrated how the cluster had implemented various plans and programs, there were some activities that had not been implemented and some farmers had not repaid the loans they had drawn from the external financier. One farmer mentioned that the cluster usually kept its promises, but there were often changes.

In Bukidnon and Davao, the cluster members believed that the clusters kept their promises as evidenced by the cluster complying with the terms and conditions established by the buyers. However, in Davao, some individual members had not kept their promises, failing to pay a proportion of the income they had derived from the sale of their vegetables to the cluster seed fund. They were other instances where farmers had failed to meet their obligations and insufficient produce was available for consolidation or the time of delivery was not followed.

\section{CONCLUSIONS}

Social capital in the form of affiliations and networks, open communication, social cohesion and high levels of trust benefited the cluster marketing groups in many ways. External partners assisted in the implementation of clustering activities, helping to overcome some of the problems associated with accessing information, training, credit, the supply of farm inputs and new technologies. Social cohesion among the cluster members contributed to the implementation of programs and promoted cooperation among the members. Open communication through regular meetings provided a positive environment for cluster members to build trust.

One of the key elements in building trust was the transparency within the cluster in terms of exchanging market information and the complete disclosure of cluster transactions. Although it was important to have trust in their cluster leader, the most important ingredient was the mutual trust and respect that the cluster members shared among themselves. Cluster members recognised that in order to retain their buyers, they had to trust one another to deliver what they had promised.

\section{ACKNOWLEDGEMENT}

This paper is part of the results of a four year research project entitled "Enhancing the profitability of selected vegetable value chains in the Southern Philippines". It is a joint program between the Philippine Council of Agriculture, Forestry and Natural Resources Research and Development, funded by the Australian Centre for International Agricultural Research. 


\section{Literature cited}

Batt, P.J., Concepcion, S.B., Hualda, L.A., Migalbin, L., Montiflor, M.O., Manalili, N.M., McGregor, M.J., Murray-Prior, R. and Rola-Rubzen, M.F. 2006. Exploring the antecedents and consequences of trust between vegetable farmers and their preferred trading partners in Southern Mindanao in Batt, P.J (ed), Proceedings of the First International Symposium on Improving the Performance of Supply Chains in the Transitional Economies. Acta Horticulturae 699: 91-102.

Bowles, S. and Gintis, H. 2002. Social capital and community governance. Economic Journal, 112: 419-436.

Brenkert, G.G. 2000. Trust, morality and international business. In Lane, C. \& Bachmann, R. (Eds.), Trust within and between organisations. Oxford University Press: 273-297.

Feldman, T.R. and Assaf, S. 1999. Social Capital: Conceptual Frameworks and Empirical Evidence. An Annotated Bibliography. World Bank. Washington DC.

Fukuyama, F. 1995. Trust. The social virtues and the creation of prosperity. NewYork Free Press.

Gitell, R. and Vidal, A. 1998. Community Organizing: Building social capital as development strategy. Sage Publications. Newbury Park, USA.

Granovetter, M. 1985. Economic action and social structure: The problem of embeddedness. American Journal of Sociology 91: 481-510.

Parthasarathy, D. and Chopde, V.K. 2000. Building social capital: collective action, adoption of agricultural innovations, and poverty reduction in the Indian semi-arid tropics. Paper prepared for the Global Development Network, International Crops Research Institute for the Semi-Arid Tropics, India.

Ostrom, E. 2000. Social Capital: A Fad or Fundamental Concept? In Dasgupta, P. \& Seragilden, I. (Eds.), Social capital: A multifaceted perspective. World Bank. Washington DC.

Productivity Commission. 2003. Social capital: Reviewing the concept and its policy implications, Research paper. Canberra.

Putnam, R.D. 1993. Making democracy work: Civic traditions in modern Italy. Princeton University Press.

Woolcock, M. and Narayan, D. 2000. Social Capital: Implications for Development Theory, Research, and Policy. World Bank Research Observer 15(2), World Bank. Washington D.C.

World Bank. 1998. The initiative on defining, monitoring and measuring social capital: Overview and program description. Social capital initiative working paper no.1. Washington DC.

Zucker, L.G. 1986. Production of trust: Institutional sources of economic structure, 18401920. Research in Organisational Behaviour 8: 53-111. 